\title{
FINALITY OF INDONESIAN CONSTITUTIONAL COURT DECISION IN REGARD TO JUDICIAL REVIEW
}

\author{
Suwarno Abadi* \\ Constitutional Law Department, Faculty of Law Universitas Wijaya Putra, Surabaya \\ Jalan Raya Benowo Nomor 1-3, Surabaya, Jawa Timur 60197
}

\begin{abstract}
This article examines the constitutional status of Constitutional Court's decisions constitutionally guaranteed as final. This status very critical because it could lead Constitutional Court to the judicial supremacy position. This article argues against this possibility. The status of Constitutional Court's decisions should be critized on the basis that its finality is prima facie, not absolute. As a solution, this article takes a position called departmentalism which means that court and legislature are not supreme in their authority to interpret the constitution.
\end{abstract}

Keywords: Constitutional Court's decisions, finality, departmentalism.

\section{Intisari}

Artikel ini membahas tentang status konstitusional putusan Mahkamah Konstitusi yang dijamin konstitusi bersifat final. Status tersebut sangat kritikal karena dapat mengarahkan Mahkamah Konstitusi ke posisi supremasi yudisial. Artikel ini berargumen tidak setuju atas kemungkinan tersebut. Oleh karena itu, status putusan Mahkamah Konstitusi perlu dikritisi dengan dasar bahwa finalitasnya tersebut bersifat "prima facie", tidak absolut. Sebagai solusinya, artikel ini mengambil posisi departementalisme yang memiliki pengertian bahwa pengadilan dan legislator tidak memiliki supremasi atas kewenangan untuk melakukan interpretasi konstitusi.

Kata Kunci: putusan Mahkamah Konstitusi, finalitas, departementalisme.

\section{Pokok Muatan}

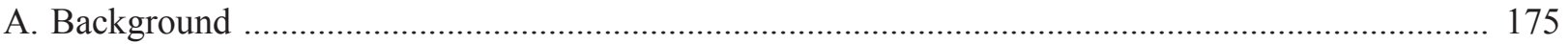

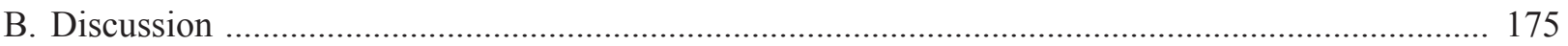

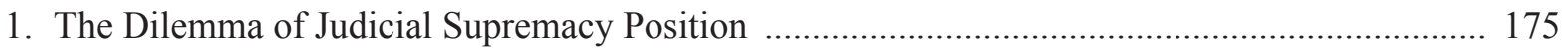

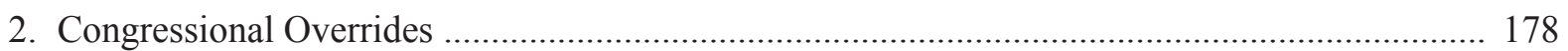

3. Re-interpretation of the Constitutional Court's Decision Finality ............................................ 182

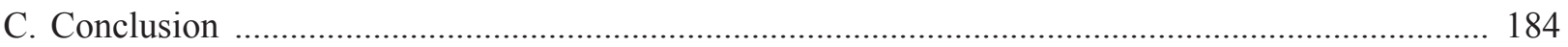




\section{A. Background}

Juridicaly, decisions made by Constitutional Court of the Republic of Indonesia in regards of judcial review over the constitutionality of an Act is final. ${ }^{1}$ It is interesting to further assessed and reviewed the essential meaning of such decision, especially in regards with its finality. Final in the sense that there are no available legal remedies towards the Constitutional Court decision because the constitutional proceeding done by Constitutional Court act as the first and last instance.

Fajar Laksono Soeroso have analyzed the issues on finality of Constitutional Court's decision with the orientation to found its philosophical ground. ${ }^{2}$ Fajar Laksono Soeroso generally argue that Constitutional Court decision is final due to these reason: First, the nature of constitutional law as the supreme law; Second, maintaining the authority of constitutional judiciary; and Third, there is no better alternative. ${ }^{3}$ This argument can be classified as a formalized perspective that localized the status of Constitutional Court decision only as decision itself, and ignoring the other factors that are very important which is the relation between the Constitutional Court and the legislator (lawmakers), which are the House of Representative and the President.

In regards to the first point, the author do agree that what was stated in the constitution has been stren and explicit. Although, if the first point to be connected with the second point, it should not be interpreted that way. When the position is formally maintained, it could implicates judicial supremacy which contradicts with the main conception of post politic reformation 1998 with four amendments to our constitution, which is checks and balances. Therefore it can be said that the Indonesian Constitution 1945 have a strong commitment towards checks and balances, so that the judicial supremacy supposedly should not happened as well as parliament supremacy and executive supremacy. The only one that could exist is constitutional supremacy, and commitment of the constitution regarding checks and balances should be more prioritized rather than judicial supremacy.

Thus, a school of thought will be created by re-interpreting the status of the finality of the Constitutional Court's decision to re-design the understanding in regards to the meaning of the finality in the judicial review of an Act. This is based on a main argument that the 1945 Constitution only recognize constitutional supremacy, not judicial supremacy. Solution that offered is departementalism. Based on such position the author will further argue that the finality of the Constitutional Court decision is prima facie, even relatively. In terms of the commitment towards checks and balances there will be an opportunity for the legislator or lawmaker to legitimately re-interpret the Constitutional Court decision, including to reject the decision through overrides. This problems will be highly relevant in the present day public discussion regarding attempt to recriminalize defamation of the President in which within the Constitutional Court decision elements of defamation towards the President in Indonesian Penal Code has been decided to be incostitutional and decriminalized. ${ }^{4}$

\section{B. Discussion \\ 1. The Dilemma of Judicial Supremacy Position}

Judicial supremacy in terms of constitutional interpretation only possible to occur if a judicial institution of a state was given a jurisdiction to enforce the constitution through a judicial review of an Act. Principally, not all of legal scholars are enthusiastic with the possibility of judicial

\footnotetext{
Article 24C paragraph (1) the 1945 Constitution of the Republic of Indonesia.

See Fajar Laksono Soeroso, “Aspek Keadilan dalam Sifat Final Putusan Mahkamah Konstitusi”, Jurnal Konstitusi, Vol. 11, No. 1, March 2014, pp. 64-84.

Ibid., p. 83.

See Constitutional Court Decision No. 013-022/PUU-IV/2006 concerning review of Article 134,136 bis, 137 Criminal Code towards the 1945 Constitution of the Republic of Indonesia.
} 
supremacy. The main issues which commonly raised was the incompatibility of the practice with the democratic principles, in criticizing the practice of judicial review emerging from the Supreme Court of United States of America, a term of countermajoritarian difficulty appeared. ${ }^{5}$ This is actually a critic towards the danger of judicial supremacy in constitution interpretation through a judicial review of an Act, which considers being the opposite of the common belief (that a lawmaker who received mandate from the people).

Theoretically, judicial supremacy is an implication from the judicial review institution. Therefore, judicial supremacy does not always happened in practice of judicial review ${ }^{6}$ The concept of judicial supremacy naturally has an understanding in the context of judicial review of an Act, "the Court defines effective constitutional meaning, such that other government officials are bound to adhere not only to the Court's disposition of a specific case but also to the Court's constitutional reasoning."

The guarantee of the judicial supremacy concept is the finality status of the decision in enforcing the constitution through a judicial review mechanism. The understanding can be referred to the opinion of Judge Robert Jackson, Supreme Court of United States of America, in the case of Brown v. Allen (1953) which stated: "We are not final because we are infallible, but we are infallible only because we are final." Meaning that the Supreme Court decision is final because there are no other legal remedies available. Explaining the aforementioned statement in the context of judicial supremacy Keith
E. Whittington said: "Judicial supremacy asserts that the Constitution is what the judges say it is, not because the Constitution has no objective meaning or that courts could not be wrong but because there is no alternative interpretive authority beyond the Court." It can be concluded that with the lack of interpretative authority towards the constitution other than the judicial institution it could become an incentive for the practice of judicial supremacy.

As mentioned, judicial supremacy is naturally concerning on the leadership in the constitutional interpretation as the context of judicial review practice. ${ }^{10}$ Whittington conceptualizes it with a term constitutional leadership..$^{11}$ If formulated into a simpleconceptjudicialsupremacynaturallyexplicate about "Who is the most [...]? Or: Who should be in charge of constitution interpretation?"12 Thereby, the concept of judicial supremacy intrinsically conceive an implicit meaning that judicial institution is the front row of a constitution interpreter to lead the other governmental institutions in conducting constitution interpretation, determining the meaning of constitution in a monopolistic way in order to be a basis of government action in the future (and other core governmental institution, which is legislator or lawmaker, has to comply to the interpretation product). ${ }^{13}$

As comparison, the practice of judicial supremacy in the United States of America often got opposed even by legislator. Constitutionally, in relation with the validity of constitution interpretation by the Supreme Court of the United States, the Constitution of United States of America

\footnotetext{
The term countermajoritarian difficulty found by Alexander M. Bickel which stated: "The root difficulty is that judicial review is countermajoritarian force in our system [...]. Not necessarily a meaningless or a pernicious one by any means; always charged with emotion, but nonrepresentational - an abstraction obscuring the reality that when the Supreme Court declares unconstitutional a legislative act or the action of an elected executive, it thwarts the will of representatives of the actual people of the here and now; it exercises control, not in behalf of the prevailing majority, but against it." Alexander M. Bickel, 1986, The Least Dangerous Branch: The Supreme Court at the Bar of Politics, Second Edition, Yale University Press, New Haven, p. 16-17.

Titon Slamet Kurnia, 2013, Mahkamah Konstitusi Republik Indonesia: Sang Penjaga HAM (The Guardian of Human Rights), Alumni, Bandung, pp. 135-136.

Keith E. Witthington, 2007, Political Foundations of Judicial Supremacy: The President, the Supreme Court and Constitutional Leadership in U.S. History, Princeton University Press, New Jersey, p. 7.

Ibid.

Ibid.

Titon Slamet Kurnia, Op.cit., p. 145.

Keith E. Whittington, Loc.cit.

Titon Slamet Kurnia, Loc.cit.

Ibid.
} 
does not gives explicit guarantee over its finality. This is different with Indonesia whereas the finality status of the Constitutional Court decision is explicitly guaranteed under the Indonesian Constitution of 1945. By this, in United States of America, the practice of judicial supremacy is tend to be unstable with a striking political background in relation between the Supreme Court and the Congress as legislator. ${ }^{14}$ One of the indication can be seen showed by the Supreme Court of United States of America in claiming that the legislator and other government institution in the United Stated of America should regard to its decisions.

In the case of Cooper v. Aaron (1958), Supreme Court of the United States of America, Chief Justice Earl Warren stated:

This decision declared the basic principles that the federal judiciary is supreme in the exposition of the law of the Constitution, and that principle has ever since been respected by this Court and the Country as a permanent and indispensable feature of our constitutional system. It follows that the interpretation of the Fourteenth Amendment enunciated by this Court in the Brown case is the supreme law of the land. ${ }^{15}$

The statement of the Supreme Court in the case of Cooper v. Aaron gives a hint that judicial supremacy is important in order to enforce the constitutional supremacy into all of the government institutions. To establish constitution supremacy, it is necessary for judicial institution as the interpreter to get guaranteed over its supremacy, thus the constitution interpretation could bind other government institutions. ${ }^{16}$

Historically, the case of Cooper v. Aaron was interesting due to its background of disobedience towards the Supreme Court decisions in the case of Brown v. Board of Education (1954) initiated by Orval Faubus, the Governor of Arkansas. The decision in Brown v. Board of Education case is greatly significance in the United States of America, the decision orders the abolition of racial segregation practice which quite sensitive in the United States. In the opposition Faubus claimed that "the Supreme Court decision is not the law of the land" which makes the policy on racial desegregation in public schools as an implication of Brown v. Board of Education decision was not bound. ${ }^{17}$

The Supreme Court of the United States' position in the case of Cooper v. Aaron is quite fair, which to give a right response towards the opposition of Brown v. Board of Education decision, which contain fundamental constitutional principles. The rationale of fairness from such position can be seen from the opinion mentioned by Whittington as follows: "The Constitution cannot be maintained as a coherent law unless the Court serves as its 'ultimate interpreter', whose understandings of the constitutional text supersede any others and which other government officials are required to adopt." ${ }^{18}$ Although, in the context of the United States' constitution, such opinion does not have an explicit constitutional basis, rather only a construction of logical thoughts inferentially connected to the function of the Supreme Court of United States in enforcing the constitution whereas the interpretation product should be adhere by the government institutions in the hope that there will be coherence between constitution with laws under it.

Opposition towards Brown v. Board of Education as well as the response of the Supreme Court of United States through Cooper v. Aaron decision would not be happened if the finality of its decisions was guaranteed by the constitution, as the Constitutional Court. Meaning that to

\footnotetext{
14 This matter will further discuss by the author in the next section from this article concerning the practice of Congressional Overrides, which position the practice of the United States of America as a comparison to reconstruct the ideas that will be implemented in the relation of legislator and the MK in Indonesia.

15 Keith E. Whittington, Op.cit., p. 2-3.

6 Titon Slamet Kurnia, Op.cit., p. 147.

Keith E. Whittington, Op.cit., p. 11.

Ibid., p. 4.
} 
get into the position of judicial supremacy, the Supreme Court of United State should fight for its authority as constitution interpreter when facing the disobedience of other government institutions. In that kind of context the author rather questioning the position of the Constitutional Court which relatively to be more established than the Supreme Court of the United States: Whether with the guarantee given over its decisions, the other institutions especially legislator must comply with the constitution interpretation product made by the Constitutional Court? As promised, the focus of this article will be on re-interpretation of the finality of Constitutional Court decisions in terms of judicial review of an Act as well as a re-design over the understanding of finality in its connection with the institutional relationship between the Constitutional Court and legislator. The most important thing here is the position of the Constitutional Court when facing the legislator as a democratic decision maker in a form of an Act. If Indonesia recognized as democratic state the existence of the Constitutional Court will be mutatis mutandis similar as the Supreme Court of the United States where Alexander M. Bickel have been assertively stated that "judicial review is a deviant institution in the American democracy." 19

\section{Congressional Overrides}

The perspectives that oppose practice of judicial supremacy in constitution interpretation represented by Thomas Jefferson, the President of the United States of America, initiating the concept of departmentalism. Explaining Thomas Jefferson's concept of departmentalism, Whittington stated:

the Jeffersonian idea that each branch of government has an equal authority and responsibility to interpret the Constitution when performing its own duties [...]. For the departmentalist, the Court's interpretations of the Constitution might be persuasive or adequate, but the Court has no special institutional authority to say what the
Constitution means. The judiciary is one institution among many that is trying to get the Constitution right, but the other branches of government have no responsibility to take the Court's reading of the Constitution as being the same as the Constitution itself. ${ }^{20}$

Departmentalism concept put government institutions, including judicial institution in the equal position of function and authority in regards to constitution interpretation. Therefore the interpretation product made by judicial institution was only being regarded as persuasive measure by other government institutions. ${ }^{21}$

In conceptual theory, the judicial review institution can be seen as a solution for the problem of absolutism that potentially arises by the practice of parliament supremacy. Jeffrey Goldsworthy explain the nature of parliament supremacy as follows:

Every statute that Parliament enacts is legally valid, and therefore that all citizens and officials, including the courts, are legally obligated to obey it. The courts' legal obligation is therefore to interpret and apply every statute in a way that is consistent with Parliament's legal authority to enact it, and their corresponding obligation to obey it. ${ }^{22}$

The judicial review institution situated in the opposite point of parliament supremacy. Thereby, from one opposite end to the other opposite end is a highly dangerous solution.

In one of Thomas Jefferson's letter that addressed to Abigail Adams, he explicitly express his criticism on the implication of judicial review of an Act towards legislator as follows: "The opinion which gives to judges the right to decide what laws are constitutional, and what not, not only for themselves in their own sphere of action, but for the Legislature and Executive also, would make the judiciary a despotic branch." ${ }^{23}$ Legislator tyranny (with parliament supremacy) replaced with judicial

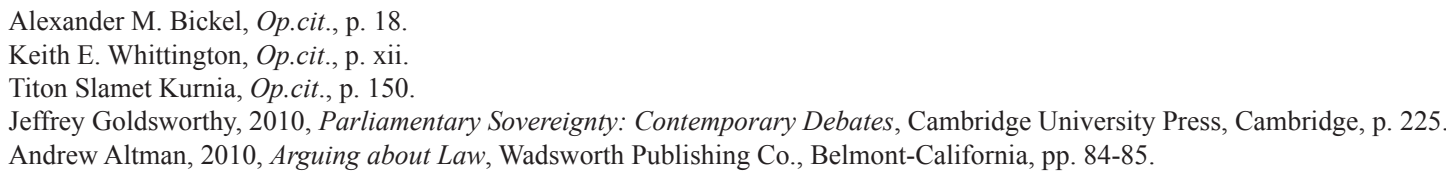


tyranny (with judicial supremacy) it is clearly not an ideal constitutional situation if assessed from the perspective of constitutionalism principles. Both of the extreme opposite points, problems and solution, should be assesed in depth. The assessment was unfortunately missed in the third amendment of the 1945 Constitution which one of the purposes was to initiate the Constitutional Court. ${ }^{24}$ The logical implication which later arise, but never been thought before was the potential of judicial supremacy by the Constitutional Court that is hard to reconcile with the constitutionalism principles.

Charles Howard McIlwain explain that the concept of constitutionalism contain the meaning of antithesis despotic/arbitrary government, which is: "in all its successive phases, constitutionalism has one essential quality: it is a legal limitation on government; it is the antithesis of arbitrary rule; its opposite is despotic government, the government of will instead of law." ${ }^{25}$ Further Mcllwain stated that two fundamental elements from the concept of constitutionalism are: "the legal limits to arbitrary power and a complete political responsibility of government to the governed." ${ }^{26}$ The potential of judicial supremacy in terms of constitution interpretation done by the Constitutional Court is broadly open, because one if its pre-conditions has been fulfilled, which is the guarantee over the finality of its decisions. In one hand, the guarantee given by the Constitution gives a strong juridical implication as a limitation of the legislative authority hold by the House of Representative and the President. Yet in the other hand it creates another problem, because there are no available legal remedies over A Constitutional Court decisions. Due to that reasons, the constitution interpretation by the Constitutional Court has fulfilled the requirements to be categorized as parallel with the concept of judicial supremacy because in accordance with Whittington's opinion: "the Constitution is what the judges say it is, not because the Constitution has no objective meaning or that courts could not be wrong but because there is no alternative interpretive authority beyond the Court."

With such tendency the author hardly deny Thomas Jefferson's belief that jurisdiction of judicial review can reformed a judicial institution to be "a despotic branch" that contradicts with the principles of constitutionalism. This is where the relevance of departmentalism in answering problems concerning judicial review institution with the relation between judicial institution (the Constitutional Court) which has judicial review jurisdiction and the legislator (the House of Representative and the President) which the legislative product being put as an object of reviewed. Consistent with the common understanding, problems that arise along with the concept of judicial supremacy is the needs of control over judicial institution. ${ }^{27}$ In accordance with the opinion of Thomas Jefferson, departmentalism gives the opportunity to conduct checks and balances equally amongst government institutions as the logic of constitutional-democratic.

Correspondingly, as a comparison, the practice of Congressional Overrides in the United States can be referred to in constructing a theoretical framework that is more sufficient to understand future institutional relation between the Constitutional Court and the legislator concerning the authority of government institution to conduct constitution interpretation. ${ }^{28}$ Before going into further specific on the practice of Congressional Overrides, the author will first explain about the underlying framework. Congressional Overrides is a response over the institutional position of a judicial institution that has countermajoritarian difficulty

\footnotetext{
Titon Slamet Kurnia, Op.cit., pp. 117-120.

Charles Howard McIlwain, 1947, Constitutionalism: Ancient and Modern, Cornell University Press, New York-Ithaca, pp. 21-22.

Ibid., p. 146.

Barry Friedman, "The History of the Countermajoritarian Difficulty, Part One: The Road to Judicial Supremacy", New York University Law Review, Vol. 73, 1998, p. 354.

28 i.e. in relation with the present debate concerning R-KUHP that is going to re-criminalized defamation towards the President or the Vice President which has been decriminalized by the MK due to inconstitutional reason.
} 
regarding its relation with the legislative institution. The practice of Congressional Overrides describes as an effort by the legislative institution to check over the judicial institution. ${ }^{29}$ The Congressional Overrides itself naturally means a disagreement of the Congress over a constitution interpretation made by the Supreme Court through its decisions. The focus of the Congress in conducting overrides is the involvement of judicial institution in the policy-making or judicial-law-making that lessen the legislative power in its hand. The practice of overrides itself naturally an effort to overcome countermajoritarian difficulty faced by judicial institution. ${ }^{30}$ The practice of overrides including "passing a new statute or amending an existing statute." ${ }^{31}$ The implication of such action is to annul the decision of the Supreme Court as long as it is in regards to the enforceability of an Act.

According to William N. Eskridge, Jr., the practice of Congressional Overrides commonly pursued in the situation "when a Supreme Court interpretation reveals an ideologically fragmented Court, relies on the text's plain meaning and ignores legislative signals, and/or rejects positions taken by federal, state, or local governments." ${ }^{32}$ In line with that argument, overrides done by the Congress seems to be in the spirit of checks and balances, especially as the corrective measure towards a Supreme Court decisions which deemed to be not correct by the Congress.

Congressional Overrides can also be done in a form of constitution amendment. Although, such kind of mechanism is rarely done. Historically there are several practices of overrides that is done through constitution amendment. First, Chisholm v. Georgia (1793) case. This case is about the Supreme Court of United States decision that receives a claim from foreign nationality citizen towards the state of Georgia. This decision was overrides by the XI Amendment of the Constitution of the United
States of America, which stated: "The judicial power of the United States shall not be construed to extend to any suit in law or equity, commenced or prosecuted against one of the United States by citizens of another State, or by citizens or subjects of any foreign State." Second, Dred Scott v. Sandford (1857) case. This case is about the omission over right to claim by Dred Scott an African-American former slave that claims for protection under equal protection clause. This decision was overrides with the XIII Amendment of the Constitution of United States of America, which stated: "Neither slavery nor involuntary servitude, except as a punishment for crime whereof the party shall have been duly convicted, shall exist within the United States, or any place subject to their jurisdiction" and the XIV Amendment of the Constitution of the United States of America stated: "All persons born or naturalized in the United States, and subject to the jurisdiction thereof, are citizens of the United States and of the State wherein they reside. No State shall make or enforce any law which shall abridge the privileges or immunities of citizens of the United States [...]".

Third, Pollock v. Farmers' Loan \& Trust Co. (1895) case. This case is about the decision of the Supreme Court of the United States that decides that the Congress'Act, which made uniformity on income tax, was unconstitutional. This case was overrides with the XVI Amendment of the Constitution of the United States of America, which stated: "The Congress shall have power to lay and collect taxes on incomes, from whatever source derived, without apportionment among the several States, and without regard to any census or enumeration." Fourth, Oregon v. Mitchell (1970) case. This case is about the Supreme Court decision that decided the unconstitutionality of Congress' Act, which is the Voting Rights Act (1970), concerning regulation of voting rights for the citizen of age 18 years old in the regional state election. This Act lowers

\footnotetext{
Deborah A. Widiss, "Shadow Precedents and the Separation of Powers: Statutory Interpretation of Congressional Overrides", Notre Dame Law Review, Vol. 84, 2009, pp. 513-514. 
the citizen's age requirements of 21 years old to have voting rights into 18 years old for federal or regional state election. This case was overrides with the XXVI Amendment of the Constitution of the United States of America, which stated: "The right of citizens of the United States, who are eighteen years of age or older, to vote shall not be denied or abridged by the United States or by any State on account of age." ${ }^{\prime 3}$

While override cases in a form of highly significant Act was a response of the Congress and the legislative institution of regional state towards the decision made by the Supreme Court of the United States regarding the abolition of capital punishment in the Criminal Act. In Furman v. Georgia (1972) case, the Supreme Court of United States gives greatly progressive decision, which stated that capital punishment is unconstitutional due to the reason that it was a practice of cruel and unusual punishment so that its existence in the Act was violating VIII Amendment of the Constitution of the United States of America. As the implication from the Furman v. Georgia case, all of federal Act and regional state Act that contain capital punishment is revoked by the Supreme Court of the United States. ${ }^{34}$ This decision was opposed by the majority of regional states and federal government which gives opposite opinion that the capital punishment does not always be cruel and unusual. Thirty-five of regional states and federal government "revive" the capital punishment by "passing new death penalty laws with added procedural safeguards to protect against arbitrary and capricious executions." ${ }^{\prime 35}$

Towards that particular situation the Supreme Court of United States does not give a negative response by defending their arguments in Furman v. Georgia decision and actually annulled the overrides. In the contrary the Supreme Court of the United States understand the override set out for them in the Furman v. Georgia decision. Judge Stewart delivered the perspective of the Supreme Court of the United States in Gregg v. Georgia (1976) decision, which stated:

Despite the continuing debate, dating back to the 19th century, over the morality and utility of capital punishment, it is now evident that a large proportion of American society continues to regard it as an appropriate and necessary criminal sanction. The most marked indication of society's endorsement of the death penalty for murder is the legislative response to Furman. The legislatures of at least 35 States have enacted new statutes that provide for the death penalty for at least some crimes that result in the death of another person. And the Congress of the United States, in 1974, enacted a statute providing the death penalty for aircraft piracy that results in death. ${ }^{36}$

Further, in this case the Supreme Court of the United States also acknowledge the constitutionality of capital punishment in the new Criminal Act as an override over the Furman v. Georgia decision with the phrase of "capital punishment laws as being constitutional so long as adequate additional procedural safeguards were afforded to capital punishment litigants." ${ }^{\prime 37}$

The aforementioned practice describes a healthy constitutional dialog in the process of constitution interpretation between the Supreme Court of the United States and the legislative power and the regional states who is done the override. Such practice should function to prevent rivalry between judicial institution which has a judicial review authority with the legislator whereas each claiming the supremacy of one another. Additionally, such practice could also avoid the judicial institution from critical allegations about its countermajoritarian position also as deviant institution in a democratic country (Alexander M. Bickel).

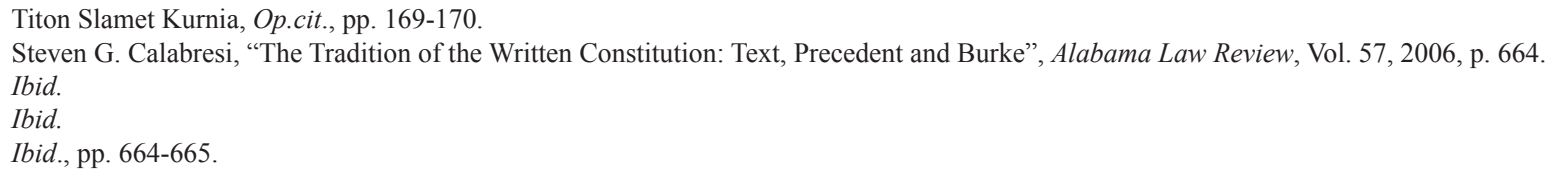


Theoretically, the legitimation of the judicial review institution can be dependent with the righteousness of its constitution interpretation product. Therefore a mistake could result a very serious problem for the legitimacy of its existence. ${ }^{38}$ In the thoughts of judicial review, one of the reasons to gives such a big authority to the judicial institution is its institutional character which hardly function as tyrant for the citizen (the least dangerous branch). Alexander Hamilton who wrote in Federalist No. 78 gave the belief as follows:

Whoever attentively considers the different departments of power must perceive, that in a government in which they are separated from each other, the judiciary, from the nature of its functions, will always be the least dangerous to the political rights of the constitution; because it will be least in a capacity to annoy or injure them. The executive not only dispenses the honors, but holds the sword of the community. The legislature not only commands the purse, but prescribes the rules by which the duties and rights of every citizen are to be regulated. The judiciary on the contrary has no influence over either the sword or the purse, no direction either of the strength or of the wealth of the society, and can take no active resolution whatever. It may truly be said to have neither Force nor Will, but merely judgment; and must ultimately depend upon the aid of the executive arm even for the efficacy of its judgments. ${ }^{39}$

However, Altman shows the weakness of Hamilton argument: "there are few democratic controls on a Court that is abusing its power." 40 Altman's critics in contradicts from the assumption that even though it is less dangerous but the judicial institution also capable in doing abuse of power which make it possible to become tyranny for the other government institution or citizens. ${ }^{41}$ Here where the relevance of Thomas Jefferson ideas of departmentalism connected with the judicial review of an Act. Departmentalism relativize dominant position of judicial institution in conducting judicial review as well as giving a room of participation for the legislator in order to conduct constitution interpretation. This is a highly positive in order to prevent a misunderstanding over the judicial institution in constitution interpretation so that mistakes can be corrected by the legislator.

\section{Re-interpretation of the Constitutional Court's Decision Finality}

Indonesia is different United States of America. The existence of the Constitutional Court as a constitution judiciary with jurisdiction, to conduct judicial review of an Act cannot be equalized with the practice done by the Supreme Court of the United States based on Marbury v. Madison (1803) case. One of the principal differences between both of the system is the guarantee in the attribution of judicial review authority as well as the finality status of its decision. Therefore the Constitutional Court's position is way stronger compare to the Supreme Court of the United States in its relation with the legislator. However, this becomes a problem. The Constitutional Court's position that is way too strong can become incentive for bigger judicial supremacy practice. This condition is not desired if the product of constitution interpretation contains error because there are no available legal remedies towards the Constitutional Court decision. Hence, the needs of comparison approach with the practice in the United States of America that hopefully can give institutional insight to solve the problems.

Thoughts or conception that the author try to develop is that even though constitutionally the Constitutional Court's decision is final, nevertheless, in the framework of departmentalism, its position as suggested by Thomas Jefferson: "the other branches of government have no responsibility to take the Court's reading of the Constitution as being the same as the Constitution itself." What should be underlined in the previous statement is

\footnotetext{
38 Based on the idea that the professional capacity as interpreter for judicial institution become one of the consideration in giving the judicial review authority. Titon Slamet Kurnia, Op.cit., pp. 85-96.

39 Alexander Hamilton, et al., 2003, The Federalist with Letters of Brutus (Terence Ball ed.), Cambridge University Press, Cambridge, p. 378.

40 Andrew Altman, Op.cit., p. 88

41 Ibid.
} 
that the finality of the Constitutional Court decision in judicial review is prima facie and it does not give obligation for the legislator to comply to such decision nor absolutely bound by the Constitutional Court constitution interpretation as well as the implication of the decision. Such ideas should be interpreted as inherent principles in Indonesia's constitutional system based on the Indonesian Constitution of 1945 which has commitment towards checks and balances to be conduct equally among the exists core government institutions, particularly between the Constitutional Court and legislator.

Even though, the aforementioned ideas is not explicitly supported under the constitution, yet the ideas should always be acknowledge within the constitutional system which based on strong commitment towards checks and balances in terms to guarantee the healthy constitutionalism, which is the non-existence of serious rivalry between legislator and the Constitutional Court. In such context the substantive argument to justify the ideas is that Indonesian constitutional system to be more based on constitutional supremacy rather than parliament supremacy or judicial supremacy. To enforce the constitutional supremacy so there will be neither parliament supremacy nor judicial supremacy. What exist are the checks and balances to support constitutional supremacy. Errors in constitution interpretation by the legislator or lawmaker will be corrected by the Constitutional Court through judicial review. Therefore it is only logical to apply a contrario formula that an error in constitution interpretation by the Constitutional Court could also be corrected by the legislator through overrides.

Based on the spirit of checks and balances, the finality of the Constitutional Court decision should be seen prima facie. This does not explicitly states in the Indonesian Constitution of 1945, but can be refer to the system of the Indonesian Constitutional of 1945. The author believes, departmentalism as set out by Thomas Jefferson can obtain a place in Indonesia constitutional system to answer the aforementioned problem without the need for it to be explicitly regulated. Principally an argument can be build that incorrectness cannot bound and applies as rules for other people. It rather should be corrected. Here is the importance of position in departmentalism and even more, Congressional Overrides to be institutionalized as constitutional through constitutional convention.

The author contends that the judicial review conducted by the Constitutional Court should not be interpreted as zero-sum game situation. The judicial review should open a room for dialogue and deliberation between the Constitutional Court and the legislator, specifically to establish a dialectic process in order to achieve the righteousness of constitutional. The judicial supremacy position does not suitable with the principle of constitutional supremacy, remembering that the constitution interpretation products made by the Constitutional Court has an inherent potential to contain errors. This is an extremely serious problem because institutionally the Constitutional Court faced by countermajoritarian difficulty situation.

Thus, judicial supremacy position could only be justified in the extreme situation. A situation that result the practice of judicial supremacy is legitimately explicit constitution violation by legislator in making laws, such as Human Rights violation. This is in line with Tom Ginsburg thoughts that justified judicial review, using the argument of: "judicial review can ensure that minorities remain part of the system, bolster legitimacy, and save democracy from itself." ${ }^{42}$ The inability of the minority to protect the fundamental interest in democratic dispute from the majority has to be compensate by the presence of judicial review institution as the form of warranty so that the minority's interests is not sacrificed in the name of majority's interests. With that kind of theoretical framework Ginsburg appreciates the judicial review 
as constitution that countermajoritarian in the positive sense, which is: "judicial review may be countermajoritarian but is not counterdemocratic." ${ }^{43}$

In accordance with the departmentalism to re-interpret the finality status of the Constitutional Court decision, the practice of overrides done by the legislator towards the Constitutional Court decision will need an opportunity, especially as the corrective measure in response to the error of the Constitutional Court interpretation in its decisions. In order that the practice of override would not be arbitrarily done, the reasoning should be more convincing compare to the Constitutional Court decision. A contrario legislator should convincingly shows that there is a substantial error from the Constitutional Court decision and the error cannot be left as is, but should be corrected. The Constitutional Court decision that is divided, which with a simpler majority $(5 / 4)$, is a strong signal for the legislator to do overrides with a base that the Constitutional Court itself does not have a strong ground belief in its decision over the issue of constitutionality over an Act.

While in practice, legislator themselves had done override towards the Constitutional Court decision. The practice was done in the response towards the Constitutional Court decision on the judicial review of an Act concerning State Budget (APBN) based on Article 31 paragraph (4) of Indonesian Constitution of 1945 about the allocation of $20 \%$ of the state budget for education. ${ }^{44}$ Other than that, in avoiding the high-tension of rivalry with the legislator, the practice of judicial review by the Constitutional Court have a tendency towards departmentalism by acknowledging the open legislative policy from legislator and making constitution decision with conditions. ${ }^{45}$ It can be concluded that the practice of constitutionalism in Indonesia, subconsciously accommodate departmentalism approach concerning the constitution interpretation, particularly in relation between the Constitutional Court and the legislator.

\section{Conclusion}

Indonesian Constitution of 1945, have a strong commitment towards checks and balances in order to guarantee the realization of constitutional supremacy. Although the finality status of the Constitutional Court decision is guaranteed constitutionally, that does not preclude the opportunity for constitutional dialog in accordance with departmentalism approach. To result the constitutional righteousness in terms of constitution interpretation, dialogue between the Constitutional Court and the legislator will be needed. In such position the finality status of the Constitutional Court decision under Indonesian Constitution of 1945 becomes prima facie and not absolute. Additionally, the practice of overrides by the legislator can be institutionalized through the process of constitution convention. The decision will later be depend on the legislator, whether they going to response to the Constitutional Court decision by doing overrides or not.

\section{BIBLIOGRAPHY}

\section{A. Books}

Altman, Andrew, 2001, Arguing about Law, Wadsworth Publishing Co., BelmontCalifornia.
Bickel, Alexander M., 1986, The Least Dangerous Branch: The Supreme Court at the Bar of Politics, Second Edition, Yale University Press, New Haven.

43 Ibid., p. 31. Compare with Edward Rubin, "Judicial Review and the Right to Resist", Georgetown Law Journal, Vol. 97, 2008, p. 103. Rubin qualifies that the character of countermajoritarian of the judicial review institution is not antidemocrary, but antirepresentational.

44 Dialogis process between legislator and the MK in relation with the implementation of Article 31 paragraph (4) of Indonesina Constitution of 1945 in the State Budget is very dinamic. See Decision No. 012/PUU-III/2005 (review on Act No. 36 of 2004 concerning State Budget in 2006); Decision No. 026/PUU-IV/2006 (review on Act No. 18 of 2006 concerning State Revenue and State Budget of 2007); Decision No. 13/PUU-VI/2008 (review on Act No.16 in 2008 concerning Amendment of Act No. 45 of 2007 concerning State Revenue and State Budget in 2008).Titon Slamet Kurnia, Op.cit., p. 171.

45 Concerning the interpretation of the MK decision with condition see Simon Butt, "Conditional Constitutionality, Pragmatism and the Rule of Law”, Legal Studies Research Paper - Sydney Law School, No. 09/28, 2009. 
Ginsburg, Tom, 2003, Judicial Review in New Democracies: Constitutional Courts in Asian Cases, Cambridge University Press, Cambridge.

Goldsworthy, Jeffrey, 2010, Parliamentary Sovereignty: Contemporary Debates, Cambridge University Press, Cambridge.

Hamilton, Alexander, et al., 2003, The Federalist with Letters of Brutus (Terence Ball ed.), Cambridge University Press, Cambridge.

Kurnia, Titon Slamet, 2013, Mahkamah Konstitusi Republik Indonesia: Sang Penjaga HAM (The Guardian of Human Rights), Alumni, Bandung.

McIlwain, CharlesHoward, 1947, Constitutionalism: Ancient and Modern, Cornell University Press, New York-Ithaca.

Witthington, Keith E., 2007, Political Foundations of Judicial Supremacy: The President, the Supreme Court and Constitutional Leadership in U.S. History, Princeton University Press, New Jersey.

\section{B. Article and Research Journal}

Butt, Simon, "Conditional Constitutionality,
Pragmatism and the Rule of Law", Legal Studies Research Paper - Sydney Law School, No. 09/28, 2009.

Calabresi, Steven G., "The Tradition of the Written Constitution: Text, Precedent and Burke", Alabama Law Review, Vol. 57, 2006.

Eskridge, Jr., William N., "Overriding Supreme Court Statutory Interpretation Decisions", Yale Law Journal, Vol. 101, 1991.

Friedman, Barry, "The History of the Countermajoritarian Difficulty, Part One: The Road to Judicial Supremacy", New York University Law Review, Vol. 73, 1998.

Rubin, Edward, "Judicial Review and the Right to Resist", Georgetown Law Journal, Vol. 97, 2008.

Soeroso, Fajar Laksono, "Aspek Keadilan dalam Sifat Final Putusan Mahkamah Konstitusi”, Jurnal Konstitusi, Vol. 11, No. 1, March 2014.

Widiss, Deborah A., "Shadow Precedents and the Separation of Powers: Statutory Interpretation of Congressional Overrides," Notre Dame Law Review, Vol. 84, 2009. 